\title{
Analysis on the Binary Oppositions of Django Unchained
}

\author{
Yu Chunmei* \\ Department of Foreign Language, Sichuan University of Science \& Engineering, Zigong City, Sichuan Province, \\ China \\ *Corresponding Author: Yu Chunmei, Department of Foreign Language, Sichuan University of \\ Science \& Engineering, Zigong City, Sichuan Province, China
}

\begin{abstract}
Structuralism, as a mode of thinking and methodology, is quite important to analyze the theme and meaning. The director forms the binary oppositions of the surface structure by which the plot of the movie can be developed, so as to help construct the heroic image of Django and deepen its theme and connotation. The authors, by analyzing the binary oppositions in the film from the perspective of structuralism, tries to explore its deep underlying structure, unfolds the social meaning to the audience. This study offers a different perspective of appreciation of the film.
\end{abstract}

Keywords: Structuralism; Slave Owners; Slaves; Django

\section{INTRODUCTION}

Django Unchained, an American revisionist Western film written and directed by Quentin Tarantino, is a tribute to the 1966 Italian film Diango by Sergio Corbucci. The story occurred in 1858 Texas, two years before American Civil War, a German bounty hunter King Schultz bought the slave Django from the slavers. As Django can identify the Brittle brothers, Dr. Schultz offered him his freedom in exchange for help tracking them down. The film was nominated for several film industry awards, including five Academy Awards after it was released in 2012 in the United States. It has aroused the interests of research of many scholars and film critics, and most of the studies focused on the frames, themes, music and characters set in the film. This study was designed to investigate contradictions and conflicts that exist in the movie Django Unchained by analyzing the binary oppositions of structuralism, so as to exploit the theme and connotation conveyed in the movie.

Structuralism is considered to be a methodology that studies the elements of human culture through their relationship to a larger, overarching system or structure. It seeks to uncover the structures that underlie all human's cultural behaviors. Binary opposition is an important concept of structuralism, a pair of related terms or concepts that are opposite in meaning, such as poor and rich, pretty and ugly, tall and short and so on. One of the two opposites assumes a role of dominance over the other. Structural linguists consider binary oppositions as rules governing not only the system of linguistic signs but the diverse systems of signs of human cultural activities. Structuralism as a mode of thinking and methodology can be applied in appreciation of movies, with binary oppositions by which the deep structure of a movie can be analyzed. The plot of the movie is about how a slave managed to fight for freedom for his wife and himself with the help of a German bounty hunter, but for structural linguists the theme of the movie is defined in the pairs of binary oppositions instead of the superficial meaning.

\section{Materials ANd Methods}

A qualitative case analysis from the approach of linguistics will be conducted. With the plot of the movie Django Unchained as the basis and the binary oppositions of structuralism as the guideline, the author seeks to analyze the pairs of binary oppositions out of which the deep theme and connotation of the movie is produced and interpreted. The in-depth analysis itself, however, reveals how binary oppositions of structuralism can be possibly applied in Quentin Tarantino's movie criticism.

\section{ThEORETICAL FRAMEWORK-BinARY OPPOSITIONS OF STRUCTURALISM}

Structuralism in Europe developed in the early 1900s, in the linguistics of Ferdinand de Saussure and the subsequent Prague, Moscow and Copenhagen schools of linguistics. Ferdinand de Saussure was 
the originator of the twentieth century reappearance of structuralism, and evidence of this can be found in Course in General Linguistics, written by Saussure's colleagues after his death and based on student notes. His distinctions between langue and parole, as well as pairs of binary oppositions are considered to be the most important relations in structural theory. Structuralism, summarized by philosopher Simon Blackburn, is "the belief that phenomena of human life are not intelligible except through their interrelations. These relations constitute a structure, and behind local variations in the surface phenomena there are constant laws of abstract culture". (Blackburn, 2008) Structuralism has been defined by Levi Strauss as "the search for the underlying patterns of thought in all forms of human activity.” (Doland, 2009)

All the structural linguists hold that the objects of the human or social sciences are relational rather than substantial, and they practice a critical method of inquiring into and specifying the sets of relations (or structures). The French anthropologist, Claude Levi-Strauss, applied Saussurian linguistics to the study of cultural phenomena, which renders structuralism rise to prominence in France. He assumes that cultures, like languages, can be viewed as systems of signs and analyzed in terms of the structural relations among their elements. Another important structuralist after Saussure is Roman Jacobson who believes that human behavior is governed by an abstract formal principle named as the binary oppositions which help reveal the meaning of a story. Greimas holds the belief that there are two aspects of an entity, namely its opposite and its negation, which are the elementary structure in our recognition and distinction. The French structuralist, Todorov, explores the structures inherent in literary discourse instead of the interpretation for the work's meaning. He believes that the structure of the narrative consists of three parts, namely the verbal (language), the semantics (content), and the syntactic (plot).

According to Ferdinand de Saussure, the binary opposition is the means by which the units of language have value or meaning; each unit is defined in reciprocal determination with another term as in binary code. It is not a contradictory relation but a structural, complementary one. (Fogarty, 2005) Binary opposition is an important concept of structuralism, which sees such distinctions as fundamental to all language and thought. It is the contrast between two mutually exclusive terms, such as on and off, up and down, left and right. (Baldick, 2004) Structuralists seek to find out the binary oppositions on foundation no matter what they studied. Binary opposition is the system by which, in language and thought, two theoretical opposites are strictly defined and set off against one another. (Smith, 1996) Saussure demonstrated that a sign's meaning is derived from its context (syntagmatic dimension) and the group (paradigm) to which it belongs. (Lacey, 2000) Saussure believed that language can be analyzed as a formal system of differential elements dependent on each other, and the value of any one element relies on the coexistence of other elements. For example, the value of "slave owner" is dependent on the existence of "slave" that was produced by the slavery of the United States; the signifier - "the slave owner" will lose its value without the existence of "slave". Therefore, any one word or sentence in the language system cannot be self-sufficient in meanings; instead, it expresses its value and meanings by forming binary oppositions between other words or sentences.

\section{RESUltS AND DISCUSSION}

Quentin Tarantino's films are characterized by an aestheticization of violence, and criticized for their use of violence and blood in an entrancing yet simultaneously repulsive way, from movies including Pulp Fiction, Kill Bill, Inglourious Basterds in his early times to Django Unchained. Do the audiences just feel thrilled with the violent and bloody scenes or moved by the hero's bold struggle for their freedom? In his Myth and Meaning, Levi Strauss proposes that the inherent structures exist in various manifestations, and one can find the fundamental meanings only if he discovers the deep structures. He also believes that a myth consists of juxtaposed binary oppositions and the human mind thinks fundamentally in these binary oppositions and their unification (the thesis, antithesis and synthesis triad), and that these are what make meaning possible. What possible fundamental meanings can we discover through the superficial elements, the violent and bloody scenes? According to Roland Barthes, the structuralists can deconstruct the text and interpret its meanings after they discover the pairs of binary oppositions and their relations. (Charles, 2004) The theme and idea the director wants to express in the movie will never be the bloody violence, but the miseries the slaves suffered through create the deeper structures - the binary oppositions including resistance and submission, enjoyment and suffering, as well as civilization and savage. 


\subsection{The Opposition between Enjoyment of Slave Owners and the Suffering of Slaves}

The description of the slaves' miserable life, thanks to which the slaver owners' luxury life is quite evident in the movie: a group of slaves with countless beaten scars and the heavy shackles were driven by the slavers at the beginning of the movie, male slaves were forced to fight to death in brutal wrestling matches with their companions by which they may have the possibility of surviving. Those slaves who tried to run away due to no longer enduring the humiliation and suffering were torn to pieces by the attacking dogs, cruelly whipped or carved with letters under the orders of the slave owners. Some of the female slaves were even forced to satisfy the slave owners' sexual demand. The sadistic tendency and atrocities of the slave owners were vividly portrayed in all these scenes.

Under the injustice of slavery in the United States, the slaves were treated as animals wantonly sold off and killed, enduring an inhuman and desperate life, while the slave owners cruelly abused slaves, enjoying a luxury life. Slaves who were considered to be a part of the slave owners' properties with neither thoughts nor feelings were forced to work exhaustingly day and night or driven to the slave market to be sold. Most of their resistance ended up with cruel torture or brutal killing. The slaves were treated as tools cruelly exploited and abused by the slave owners, on which their luxury and privileged life was built.

\subsection{The Opposition between Django's Persistent Struggle and Other Slaves' Servile Obedience}

Like other slaves, Django was exploited and abused by the slave owners in the beginning of the movie. He tried escaping with his wife from the torture but failed, which resulted in their being sold off separately to different owners. He was freed by a German bounty hunter King Schultz when being driven on foot to another hell. With the help or King, he killed his former enemies - the three Brittles bravely and decisively, which was quite appreciated by King. Helped and fully trained by Dr. Schultz, Django soon grew to be an excellent bounty hunter, trying to rescue his wife Broomhilda from the slavery of Calvin Candie, the cruel owner of the Candyland plantation. They had collected huge wealth after the winter, but Django cared more about his plan to rescue his wife, Broomhilda.

Django's rebellious spirit has been depicted many times in the film. i. when being asked about his plans as a free man, Django replied that he wanted to redeem his wife from her slave owner, which proves that he had the belief that he was able to rescue his wife and determined to do so. ii. The memory of their being whipped cruelly came into his mind after he recognized the brutish Brittles, which drove Django to pull a gun on one of them and whip wantonly the other one, releasing his intense rage and hatred. iii. When witnessing his wife's being humiliated and abused, Django tried several times pulling the gun to save her, but he soon came to his senses because King and he had a deliberate plan. iv. The movie ended up with a surprisingly bloody and violent gunplay, which aims at highlighting Django's desperate fighting for freedom. Unfortunately, due to his being hopelessly outnumbered, Django was arrested again and driven to LeQuint Dickey, but he had the wit to turn back and destroyed all the enemies successfully.

Compared with the persistent struggle, other slaves showed servility and subservience. i. At the beginning of the movie, after Dr. Schultz killed one of the slaves, leaving another seriously hurt, and Django has been rescued, other slaves didn't try to run away immediately although the living one was unable to detain them, instead, they chose to wait for the permission of King Schultz before trying to free themselves. ii. Stephen, the black butler of Calvin Candie, tormented his fellow blacks in an extremely cruel way, so that he might please his owner and survive. iii. Ben, an old housekeeper, would rather be a slave for fifty years than risk his life cutting the slave owner's throat. iv. At the end of the movie, other slaves kept sitting still in the carriage rather than run away after the slavers were skilled by Django. Watching the Django's horse disappearing in the distance, they showed admiration for Django's brave struggle for his freedom and hope of rebirth. Unfortunately, there is no one slave so brave and determined as Django who can risk his life fighting for the freedom of both his wife and himself against the slave owners. It is other slaves' submissiveness that contrasts greatly with Django's courage and determination for freedom.

\subsection{The Opposition between Civilization and Savageness}

In the 19th century, the United States had established a relatively perfect legal system by which the whites' life and property were protected. The white people paid attention to the etiquette system, 
pretending to be gentle and polite to others except the black slaves. The seeming civilization and the developed industry of the white Americans are portrayed in the film, including the developed planting industry in the south, white slave owners' grand and splendid villas, and the gentleness shown by the plantation owner Calvin Candie to his sister, etc., compared with which the brutality and unfairness inflicted by the salves owners to the black slaves was vividly revealed. The scenes in which the black slaves were treated like animals whipped by the whites, scourged by attack dogs and sold to other whites, forced to work for an unreasonably long time, to fight to death with their companions in brutal wrestling matches, and to act as sex slaves to please the slave owners and so on, profoundly reveals the cruelty and brutality of the slave owners towards the slaves. The comparison between slave owners' politeness and gentleness to the white Americans and their cruelty and brutality to black slaves constitutes the binary oppositions of structuralism, by which the misery life of the slaves and the irreconcilable conflicts between the slave owners and the slaves are emphasized; they further promote the development of the plot of the whole movie. The plot reached the climax when the fierce bloody gunplay happened at the end of the movie by which the slave owners' elegant luxury manor was destroyed, which symbolizes that the brutality and ferocity of the slave owners to the slaves will finally be terminated because of their gallant fighting.

Of course, there are many other binary oppositions in the film, such as white and red; the former color symbolizing purity and peace, while the latter is associated with blood and violence. The sharp contrast between the two colors not only has visual impact upon the audience, but manifests Django's determination to struggle for freedom after the long time's suffering from the slave-owners' brutal oppression. However, the above mentioned pairs of binary opposition including the enjoyment of slave owners and the suffering of slaves, Django's persistent struggle and other slaves' servile obedience, and the civilization and savageness of the slave owners exist in the whole movie, constituting the basic structure of the film, based on which the main plot and theme of the movie was developed. The several binary oppositions not only help the movie reach a thrilling climax gradually, but highlight the hero's heroic personality and determination to fight for freedom, so as to deepen the theme and connotation of the film. The film ended up with Django's success in fighting for freedom and the slave owner's destruction, which benefits not only from the help of King Schultz but also his bravery as well as persistence to freedom and love.

\section{CONCLUSiON}

After removing the complicated superficial surface structure, it is not difficult to find that the binary oppositions of structuralism not only frame the series of contradictions in the film, but also constitute the basic structure of the whole film. The opposition between the enjoyment of slave owners and the abuse of slaves vividly and precisely reveals the tragedy life of the slaves to the audience. The opposition between Django's arduous resistance and other slaves' servile obedience manifests his commitment to freedom. The opposition between the civilization and brutality of the slave owners exposes not only their hypocrisy but also the cruelty to the slaves. The combination of the binary oppositions helps create the heroic image of Django and reveal the tragedy brought by the slavery to the black Americans, so as to deepen the theme and connotation of the whole film. Therefore, besides the aestheticization of violence and filming techniques applied by the director Quentin Tarantino, the success of Django Unchained lies in the appropriate combination of several binary oppositions by which the misery life of the slaves and the heroic image of Django was vividly and fully shown to the audience.

\section{REFERENCES}

[1] Blackburn, Simon. (2008). Oxford Dictionary of Philosophy, second edition revised. Oxford: Oxford University Press, ISBN 978-0-19-954143-0

[2] Baldick, C. (2004). The concise Oxford Dictionary of literary terms, viewed 8 March 2011, http://www.hi ghbeam.com/doc/1056-binaryopposition.html

[3] Charles, E. Bressler. (2004). Literary Criticism: An Introduction to the Theory and Practice [M]. Beijing: Higher Education Press. https://en.m. wikipedia.org/wiki/Structuralism

[4] Doland, Angela. (2009). "Anthropology giant Claude LeviStrauss dead at 100". Seattle Times. Associated Press. Retrieved 22 April 2015.

[5] Fogarty, S. (2005).The literary encyclopedia, viewed 6 March 2011, http://www.litencyc.com/php/stopics. php? pec $=$ true \& UID $=122$ 
[6] Lacey, N. (2000). Narrative and Genre, p.64, Palgrave, New York.

[7] Smith, G. (1996). "Binary opposition and sexual power in Paradise Lost". Midwest Quarterly. 27 (4): 383.

Citation: Yu Chunmei. "Analysis on the Binary Oppositions of Django Unchained". International Journal of Humanities Social Sciences and Education (IJHSSE), vol 5, no. 2, 2018, pp. 108-112 doi: http://dx.doi.org/10.20431/2349-0381.0502012.

Copyright: (c) 2018 Authors. This is an open-access article distributed under the terms of the Creative Commons Attribution License, which permits unrestricted use, distribution, and reproduction in any medium, provided the original author and source are credited. 